\title{
20 Minutos na Fila: sobre experiência, relato e subjetividade em Imre Kertész ${ }^{*}$
}

\author{
Jorge Larrosa Bondía** \\ Tradução $^{* * *}$ de Filipe Santos Fernandes ${ }^{* * * *}$
}

Sou diferente deles, sou diferente dos outros, sou diferente de mim mesmo.

Imre Kertész

Quero começar agradecendo à Pontifícia Universidade Católica do Rio Grande do Sul e às outras instituições organizadoras deste "I Congresso Internacional sobre Pesquisa (Auto)biográfica" por me honrarem com o convite para participar deste encontro, por me permitirem visitar novamente esta cidade na qual tenho tantos amigos e da qual guardo tantas recordações e, sobretudo, por me darem a oportunidade de compartilhar aqui, com vocês, algumas ideias, leituras e perplexidades. Agradeço também à professora Maria Helena Menna

\footnotetext{
* Conferência de abertura do I Congresso Internacional sobre Pesquisa (Auto)biográfica celebrado em Porto Alegre, Rio Grande do Sul, Brasil, em setembro de 2004.

** Professor de Filosofia da Educação na Universidade de Barcelona. Realizou estudos pós-doutorais em Paris e Londres. Autor de vários livros publicados na Espanha, Argentina, Colômbia, México, Venezuela, França e Brasil. Autor de vários artigos publicados em revistas especializadas de diversos países. Membro do Comitê Científico de revistas de vários países. Foi professor convidado em diversas universidades europeias e latinoamericanas. Seus trabalhos, de clara vocação ensaística, movem-se entre a filosofia, a literatura, as artes e a educação (sendo grande parte deles publicados no Brasil pela editora Autêntica). Seus principais temas são a relação entre a experiência e a linguagem, a experiência e a subjetividade, a experiência e a educação Enderço para Correspondência: Divisió de Ciències de l'Educació, Departamento de Teoria i Història de l'Educació. Passeig de la Vall d'Hebron, 171, Edifici de Llevant, 3a. planta. Código postal: 08035. Barcelona, Espanha. Email: jlarrosa@ub.edu.

*** O leitor encontrará, além das notas do próprio autor, notas de tradução (assinaladas) que buscam elucidar alguns detalhes do trabalho realizado. Essas notas serão, quando inseridas junto às notas do próprio autor, sinalizadas entre colchetes. Quanto aos fragmentos das obras Sin destino e Fiasco, de Imre Kertész, amplamente citados pelo autor, utilizamos as traduções em língua portuguesa publicadas pela editora Planeta do Brasil (Sem destino e $O$ fiasco). O mesmo procedimento foi realizado com as obras de Walter Benjamin e Giorgio Agamben, com edições de outras editoras. Os fragmentos de Ensayo en Hamburgo, Discurso de recepción del Nobel e Diario de la galera, também trabalhos de Imre Kertész, foram feitos livremente a partir do manuscrito de Jorge Larrosa. Vale destacar que tentamos conservar, sempre que possível, o tom do texto, em sua fluidez e em seus traços de informalidade próprios da oralidade. A tradução foi checada pelo autor e sua publicação foi por ele autorizada.

***** Doutorando em Educação Matemática pela Universidade Estadual Paulista "Júlio de Mesquita Filho" (UNESP/Rio Claro). Endereço para correspondência: Rua 8B, 1137, Vila Indaiá, CEP 13506-739, Rio Claro, São Paulo, Brasil. E-mail: fernandes.fjf@gmail.com.
} 
Barreto Abrahão ${ }^{1}$, que me acompanha nesta mesa, pela generosidade com que tem acolhido alguns de meus escritos e, especialmente, pela confiança que tem depositado em mim ao encarregar-me a conferência de abertura. Espero responder a essa generosidade e a essa confiança abusando delas, talvez até mesmo traindo-as.

Digo isso porque sei que, em uma conferência de abertura se espera, além de uma contribuição específica para o tema do Congresso, algo como uma contribuição de caráter geral sobre a importância deste tema tanto do ponto de vista teórico como do ponto de vista prático e, até mesmo, político. Algo que nos permita nos sentirmos inteligentes, trabalhadores, inovadores, progressistas, úteis a sociedade. Algo que nos permita legitimar nosso trabalho, ou, inclusive, dizendo de um modo mais prosaico, justificar o gasto. No entanto, eu queria começar expressando algumas de minhas reservas em relação à pesquisa (auto)biográfica e, sobretudo, em relação à pesquisa (auto)biográfica em Educação. Reservas essas que tratarei de formular agora de um modo geral, mas sobre as quais voltarei - espero que de uma maneira um pouco mais afiada - ao final de minha intervenção.

Como verão a seguir, são reservas que, a julgar pelas discussões que se anunciam no programa do Congresso, e a julgar também pelo que eu tive oportunidade de ler nos trabalhos de alguns dos participantes, muitos de vocês compartilham. Na verdade, nós, que estamos dedicados à pesquisa social, aos estudos culturais, ou, mais especificamente, à reflexão sobre temas educacionais, somos extremamente autocríticos, talvez até um pouco masoquistas. Como intelectuais - se é que essa palavra ainda tem sentido -, dedicamo-nos constantemente a questionar nossa própria posição intelectual. E, quando falamos da prática, ou trabalhamos para a prática, costumamos prestar muito mais atenção ao que fazemos mal do que ao que fazemos bem. Talvez nenhum campo tenha se dedicado com mais intensidade a fazer visíveis seus próprios fracassos como o da Educação. E, talvez, nenhum campo tenha sido mais feroz na revisão de sua própria maneira de construir a realidade como o da teoria social e cultural. Por isso, sei que essa forma de trair a confiança que depositam em mim não é realmente uma traição, mas uma forma de corresponder ao espírito crítico e autocrítico que sempre orientou nosso trabalho e que, não tenho nenhuma dúvida, todos nós queremos que continue a orientarnos.

1.

${ }^{1}$ N. do T.: Professora da Pontifícia Universidade Católica do Rio Grande do Sul (PUC-RS). 
A primeira reserva refere-se à evidente assimetria entre os sujeitos pesquisadores e os sujeitos pesquisados, algo que esse campo de pesquisa compartilha, sem dúvida, com os outros campos das assim chamadas ciências sociais, mas que é, aqui, irritante do ponto de vista metodológico e especialmente incômodo dos pontos de vista ético e político. Para expressar essa reserva, farei uma pequena nota autobiográfica, contando-lhes algo que me ocorreu há alguns anos próximo daqui, em Ijuí, no interior deste mesmo estado, em uma visita a um acampamento dos sem-terra, acompanhado, naturalmente, por um professor universitário militante de esquerda, por um dos dirigentes do acampamento e por uma pesquisadora declaradamente feminista que havia feito um belo trabalho sobre histórias de vida de mulheres do MST, algo que tinha a ver com questões relativamente sofisticadas e sem dúvida muito interessantes ao propósito da relação entre gênero, exclusão e identidade.

$\mathrm{Eu}$ sempre resisto ao que poderíamos chamar turismo social, essa forma de turismo que propõe visitar favelas, comunidades indígenas ou bairros populares. Eu não gosto do modo como temos convertido a pobreza em algo fotogênico, algo que fica bem nos álbuns de fotografias que costumamos fabricar à volta de nossas viagens. Eu não gosto dos relatos que esse tipo de turismo costuma produzir, esses relatos tecidos de assombro, arrogância, boa consciência e boa vontade. Não posso evitar a sensação de que em nossas viagens à miséria andamos buscando imagens para mostrar, histórias para contar, troféus de caça para exibir. Mas, apesar de minhas preocupações, estava eu ali, embaixo de um desses toldos de plástico negro convertidos em casas, aceitando o mate que me oferecia uma mulher cujo nome não recordo, fazendo-lhe uma pergunta atrás da outra sobre sua maneira de viver, sobre sua família, sobre o que a trouxera para aquele lugar, sobre suas dificuldades, seus projetos e esperanças. Como me sentia um pouco envergonhado com a impunidade com a qual poderia fazer qualquer pergunta, inclusive as mais pessoais, as mais indiscretas, tratei de imaginar uma situação inversa: um membro do MST que chama a minha porta, que se declara interessado pelas histórias de vida dos professores universitários homens e heterossexuais de minha geração, que espia assombrado minha casa, que se deixa servir uma taça de vinho, que se sente autorizado a perguntar qualquer coisa sobre o meu modo de vida, minha trajetória pessoal, minhas expectativas, minhas ideias, meus amores, minhas conquistas e frustrações, minhas alegrias e tristezas, e que me diz que vai publicar algo sobre minhas experiências de vida em algum livro coletivo feito por pesquisadores pobres e analfabetos interessados nas formas de vida de sujeitos ricos e universitários.

A segunda reserva se refere ao que poderíamos chamar de armadilhas do reconhecimento. Se nos perguntarmos pelo pano de fundo dessa paixão memorialística, 
biográfica e autobiográfica que atravessa nossa época, encontraríamos, sem dúvida, o que poderíamos chamar de lutas pelo reconhecimento, quero dizer, lutas para que algumas modalidades de existência tradicionalmente submersas, ignoradas, desconhecidas ou menosprezadas encontrem um lugar no espaço público, o único que, como destacou Hannah Arendt, dá lugar à visibilidade, à existência. É como se estivéssemos tratando de democratizar o direito a isso que antes se chamava uma vida própria, uma identidade, uma personalidade, uma história pessoal, uma biografia singular, um destino. É como se todos os grupos sociais e culturais, todos os sujeitos individuais e coletivos, estivessem gritando: "Nós também existimos! Nós também vivemos vidas que merecem ser contadas, registradas e escutadas! Nós também somos interessantes!" Naturalmente, tudo isso tem a ver com a institucionalização da estima e da autoestima, com a mobilização de gigantescos mecanismos que canalizam tanto as demandas de reconhecimento como as necessidades de autorreconhecimento. Tem a ver também com a entrada na escola pública de novos sujeitos, com a lógica ao mesmo tempo extensiva e intensiva com a qual funcionam nossos imperativos igualitários, com a ampliação massiva e massificadora do público e com suas pretensões de abarcar a totalidade do existente.

O que ocorre é que a visibilidade generalizada tem como correlato uma banalização generalizada. Se qualquer um é extraordinário, o ser extraordinário se converte em um ser qualquer. Se todos temos o direito de se exibir, se todos tem o direito a chamar a atenção, então nada, nem ninguém se destaca, ou se destaca de um modo banal. É como se a sociedade de massas se dedicasse massivamente a fazer espetáculo de si mesma, a converter-se em espetáculo de si mesma, a consumir-se a si mesma sob a forma do espetáculo. É como se a generalização do reconhecimento conduzisse a sua banalização, como se a universalização do direito a ser alguém convertesse esse ser alguém em algo completamente insignificante.

A terceira reserva é uma chamada de atenção que diz respeito à captura biopolítica na pesquisa (auto)biográfica, ou melhor, que diz respeito a como a maioria dessas modalidades de pesquisa estão atravessadas por motivos facilmente utilizáveis pelas políticas da identidade e da identificação. Ao meu entender, isso passa por uma estranha lógica da construção identitária, segundo a qual um emigrante se converte em um emigrante, uma mulher trabalhadora em uma mulher trabalhadora, uma professora da favela em uma professora da favela, um líder indígena em um líder indígena, uma mulher agredida em uma mulher agredida, um adolescente traficante em um adolescente traficante, um policial corrupto em um policial corrupto, uma militante do MST em uma militante do MST etc. Refiro-me a essa curiosa operação de desdobramento ou de duplicação, segundo a qual qualquer pessoa 
singular e, portanto, incompreensível, inidentificável, irrepresentável e imprevisível, se converte em uma espécie de dobra de si mesma na medida em que é convertida como representante de alguma categoria genérica, de algum tipo humano que, ao mesmo tempo em que busca para si reconhecimento, converte-se em um personagem que nada mais é que a encarnação de algum estereótipo. Somente ao preço de entrar no reino do estereótipo, somente sendo construída segundo regras fixas e padronizadas, qualquer existência se faz compreensível, representável, identificável e previsível, fazendo-se suscetível de uma leitura mecânica, fácil e unidimensional. E o mesmo poderíamos dizer disso que costumamos chamar mundo, realidade, lugar, ou, usando uma palavra que a mim parece cada vez mais estúpida, contexto. O relato não constrói somente personagens, mas também lugares. É a mesma operação de duplicação e padronização que converte uma favela em uma favela, um latifúndio em um latifúndio, uma escola em uma escola e um assentamento do MST em um assentamento do MST. As políticas da identidade e da identificação necessitam de personagens e lugares perfeitamente identificados e identificáveis, personagens estereotipados que se movem em lugares igualmente estereotipados. As lógicas da identidade e da identificação somente são capazes de re-conhecer ${ }^{2}$ algo ou alguém ao preço de construí-lo como algo ou alguém já conhecido.

\section{2.}

Enunciadas essas reservas, de um modo muito geral, o que quero fazer aqui com vocês é problematizar a relação entre relato e identidade, retomar isso da identidade narrativa, reformular isso do relato autobiográfico como o lugar de elaboração e reelaboração da identidade, do que somos, de quem somos, do que nos tornamos, do que nos passa, de como nos tornamos o que somos, do que não podemos e não queremos ser, do que já estamos deixando de ser.

Devo dizer-lhes, antes de começar, que a mim sempre incomodou a identidade. De fato, meu primeiro texto sobre estes temas, um texto revisado e corrigido para fazer parte do livro que estamos apresentado neste Congresso, se intitulava Narrativa, identidad $y$ desidentificación: Notas sobre la vida humana como novela ${ }^{3}$, como se quisesse sugerir que as

\footnotetext{
${ }^{2}$ N. do T.: Em espanhol, re-conocer.

${ }^{3} \mathrm{Em}$ La experiencia de la lectura. Estudios sobre literatura y formación. Nueva edición revisada y aumentada. México: Fondo de Cultura Económica, 2003. Uma versão desse texto intitulada Notas sobre narrativa y identidade (a modo de presentación) foi publicada no livro deste Congresso, organizado por Maria Helena Menna Barreto Abrahão: A aventura (auto)biográfica. Teoria \& empiria. Porto Alegre: EDIPUCRS, 2004. 
histórias de vida fazem, mas sobretudo desfazem, isso que chamamos identidade, quero dizer, a coincidência do sujeito consigo mesmo e a maior ou menor estabilidade dessa coincidência no tempo, o que poderíamos chamar a dinâmica da identidade. Por outra parte, meu outro texto sobre autobiografia, um texto sobre as Confissões de Rousseau, se intitula Os paradoxos da autoconsciência ${ }^{4}$ e insiste também na escrita de si como um lugar em que se produzem simultaneamente a solidificação e a diluição da identidade. Além disso, meus trabalhos sobre o romance de formação ${ }^{5}$ têm a ver também com a forma como esse gênero narrativo clássico mostra a impossibilidade de pensar qualquer devir como uma apropriação identitária. Se a isso acrescentarmos as reservas que anunciamos antes sobre a relação entre a construção da identidade e as biopolíticas da identificação, vocês compreenderão que não me sinto cômodo com a identidade.

O que vou fazer hoje, dando um passo a mais nessa linha, talvez um passo atrás, ou um passo ao lado, é explorar outra vez a relação entre a experiência, o relato autobiográfico e isso que poderíamos chamar, pelo menos neste momento, o eu, o si mesmo, o sujeito, a relação que cada um de nós temos com nós mesmos, como nossa vida, com o passar do que nos passa, com o modo como compreendemos ou não a nós mesmos. A experiência é $o$ que nos passa, o relato é um dos modos privilegiados de como tratamos de dar sentido narrativo a isso que nos passa e o sujeito da experiência, convertido no sujeito do relato, é o autor, o narrador é o personagem principal dessa trama de sentido e de sem-sentido ${ }^{6}$ que construímos como nossa vida e que, ao mesmo tempo, nos constrói.

Para problematizar essa relação entre experiência, relato e subjetividade, tomarei como pretexto alguns escritos de Imre Kertész, esse húngaro que ganhou o prêmio Nobel de Literatura, em 2002, e que é autor de uma série de romances de caráter marcadamente autobiográfico nos quais trata de elaborar suas experiências tanto nos campos de concentração nazistas como na ditadura comunista de seu país. Vou considerar dois romances: Sem destino e $O$ fiasco $^{7}$. Vou considerar também dois textos mais ou menos ensaísticos em que Kertész diz algumas coisas muito importantes sobre sua própria escrita: o Ensayo en Hamburgo e o Discurso de recepción del Nobel. Por último, vou usar algumas partes de Diario de la

\footnotetext{
${ }^{4}$ Em Pedagogia profana. Belo Horizonte: Autêntica, 2003.

${ }^{5}$ Sobretudo Do espírito de criança à criança do espírito e Três imagens do Paraíso, também em Pedagogia profana. Op. Cit.

${ }^{6}$ N. do T.: Em espanhol, sinsentido.

${ }^{7}$ N. do T.: Neste trabalho foram utilizadas as seguintes traduções em língua portuguesa, publicadas no Brasil: Sem destino. Tradução de Paulo Schiller. São Paulo: Planeta do Brasil, 2003; e O fiasco. Tradução de Ildikó Sütö. São Paulo: Planeta do Brasil, 2004.
} 
galera $^{8}$, sobretudo aquelas que se correspondem com a redação dos romances que já havia comentado.

E quero adverti-lhes, também antes de começar, que vou tomar a obra de Kertész não porque nos põe as coisas fáceis, mas porque as põe difíceis. Kertész nos fala da impossibilidade da experiência, da desconstrução do sujeito e da incapacidade do relato para produzir sentido. Por isso, o tema desta conferência será, então, a relação entre uma experiência que se sabe impossível, um sujeito que se sabe destruído e um relato que se sabe insignificante.

3.

Vou começar lendo o início de uma conferência que Kertész pronunciou em Hamburgo, em maio de $1995^{9}$. O primeiro fragmento diz assim: “o conferencista [...] nasceu no primeiro terço do século XX, sobreviveu a Auschwitz e passou pelo stalinismo, presenciou de perto, como morador de Budapeste, um levante nacional espontâneo, aprendeu, como escritor, a inspirar-se exclusivamente no negativo e, seis anos depois do final da ocupação russa chamada socialismo [...], encontrando-se no interior desse vazio voraginoso que nas festas nacionais se denomina liberdade e que a nova construção define como democracia, se pergunta se servem de algo suas experiências ou se viveu tudo em vão" ${ }^{\text {. }}$.

Temos um homem cuja vida atravessa o século. Um homem que padeceu a história do século e que, em um momento quase terminal de sua vida, quase fazendo um balanço, se pergunta pelo valor de suas experiências. Se suas experiências não servem de nada, então haverá vivido sua vida em vão. Suas experiências são sua vida, o que lhe passou, o que viveu. Por isso, sua pergunta tem a ver com o valor e o sentido dessa vida tanto para si mesmo como para os outros. Uma vida em vão é uma vida insignificante, uma vida sem sentido, sem valor, nem para si mesmo, nem para os outros; uma vida que não merece atenção ou que a merece justamente por explorar a falta de sentido e de valor de qualquer vida.

E o texto continua assim: "quando falo de minhas experiências, refiro-me à minha pessoa, à formação de minha personalidade, ao processo cultural-existencial que os alemães chamam Bildung e não posso negar que a história marcou com seu selo as experiências que

\footnotetext{
${ }^{8}$ N. do T.: A tradução dos fragmentos das obras Ensayo en Hamburgo, Discurso de recepción del Nobel e Diario de la galera, todas de Imre Kertész, foi realizada a partir dos trechos disponibilizados pelo autor no manuscrito deste artigo.

${ }^{9}$ Ensayo en Hamburgo. Em Un instante de silencio en el paredón. Barcelona: Herder, 1999.

${ }^{10}$ Idem, p. 29.
} 
marcaram minha personalidade" ${ }^{\text {. }}$. Dir-se-ia que Kertész nomeia aqui a relação clássica entre experiência e formação: a experiência é o que nos passa e o que, ao nos passar, nos forma ou nos transforma, nos constitui, nos faz como somos, marca nossa maneira de ser, configura nossa pessoa e nossa personalidade. O que Kertész parece dizer é que a história produziu as experiências que determinaram sua personalidade. Ele é o que é pelas experiências que viveu, pelo modo como viveu o que seu tempo the deu a viver, lhe obrigou a viver. No entanto: "por outro lado, podemos definir, como aspecto mais característico do século $\mathrm{XX}$, o fato de ter banido de maneira completa a pessoa e a personalidade. Como estabelecer, pois, uma relação entre minha personalidade formada por minhas experiências e a história que nega e até mesmo aniquila minha personalidade?"12.

É como se o século XX nos tivesse dado a viver experiências encaminhadas a destruir a pessoa e a personalidade. e aqui está o primeiro paradoxo: as experiências desse século determinaram nossa personalidade, mas essas experiências têm como efeito a destruição da personalidade: o que determina nossa personalidade é que nossa personalidade foi destruída. E continua: "aqueles que viveram ao menos um dos totalitarismos deste século, seja a ditadura nazista ou a da foice e do martelo, compartilharam comigo a inevitável preocupação com esse dilema. Isso porque a vida de todos eles tiveram um momento em que pareciam não mais viver suas próprias vidas, em que encontravam a si mesmos em situações inconcebíveis, desempenhando papéis dificilmente explicáveis para o sentido comum e atuando como nunca atuariam se tivessem dependido de seu juízo perfeito; em que se viam forçados a fazer escolhas que não advinham do desenvolvimento interno do seu caráter, mas de uma força externa parecida com um pesadelo. Não se reconheciam completamente nesses momentos de suas vidas que, mais tarde, recordariam de forma confusa e transtornada; e os trechos que não conseguiam esquecer, pouco a pouco, com o passar do tempo, se convertiam em anedotas e, portanto, em algo estranho que não se transformava em parte constitutiva de sua personalidade, em suas vivências que poderiam ter continuidade e construí-la; em algumas palavras, de nenhum modo queriam ficar como experiência no ser humano"13.

O que eu vivi, parece dizer Kertész, o que milhões de pessoas como eu viveram, o que milhões de pessoas como eu continuam vivendo nesse vazio que as festas nacionais denominam liberdade e que as constituições definem como democracia, essa vida que transita entre os espaços de produção, de circulação e consumo, todos eles privados, mercantilizados e

\footnotetext{
${ }^{11}$ Idem, p. 29-30.

12 Idem, p. 30.

${ }^{13}$ Idem.
} 
conectados, é a sensação de não ter vivido sua própria vida, a sensação de não ter uma vida própria ou de uma vida a qual se pode chamar própria, uma vida da qual podemos nos apropriar. Nós não podemos nos reconhecer no que nós vivemos e o que vivemos não tem nada a ver com nós, foi algo estranho a nós e, por isso, não se pode converter em parte de nossa pessoa, de nossa personalidade.

O fragmento que queria ler acaba assim: "a não elaboração das experiências e, em alguns casos, a impossibilidade de elaborá-las: essa é, acredito, a experiência característica e incomparável do século XX"14. A impossibilidade de elaborar as experiências, de dar-lhes um sentido próprio, e, se as experiências não se elaboram, se não adquirem um sentido, seja qual for, em relação a sua própria vida, não podem chamar-se, estritamente, experiências. E, desde logo, não podem transmitir-se em forma de relato. E, portanto, não podem constituir isso que Kertész chama uma personalidade, uma pessoa, um indivíduo pessoal, e que nós poderíamos chamar, talvez, um sujeito ${ }^{15}$.

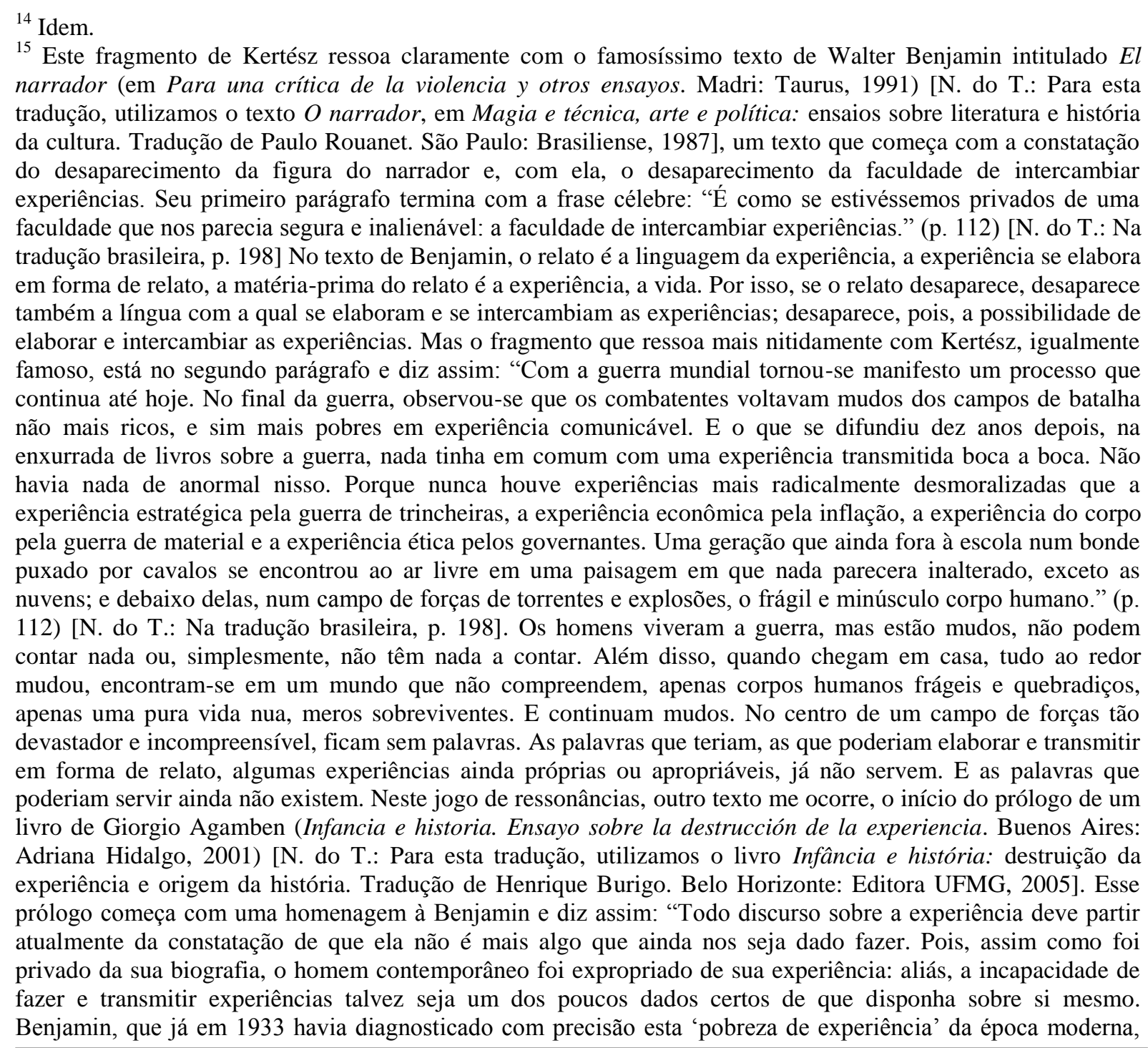


Não podemos elaborar nossas experiências porque vivemos nossa vida como se não fosse nossa, porque não podemos entender o que nos passa, porque é impossível ter uma vida própria, porque nossas vidas são insignificantes, intercambiáveis, alheias, vazias de sentido ou dotadas de um sentido falso ou falsificado, algo que nos é vendido no mercado como qualquer outra mercadoria. A experiência de quem somos é que não somos nada ou que o que somos é falso.

A primeira tese é que a experiência foi destruída e que, em troca, nos é dada uma experiência falsa. A segunda tese, correlativa da primeira, é que não há linguagem para elaborar a experiência, que nos faltam palavras ou que as palavras que temos são tão insignificantes, tão intercambiáveis, tão alheias e tão falsas como o que nos passa, como nossa vida. A terceira tese é que não podemos ser alguém, que tudo o que somos ou o que podemos ser foi fabricado fora de nós, sem nós, e é tão falso quanto imposto, que não somos nada ou que o que somos é falso. Portanto, falar da experiência, ou da formação, ou das linguagens da experiência, ou do relato como linguagem da experiência, é falar da mais pura banalidade, de algo que é falso, de algo que só existe como nostalgia ou como desejo mas, em qualquer caso, como impossibilidade.

4.

indicava suas causas na catástrofe da guerra mundial [...]." (p. 7) [N. do T.: Na tradução brasileira, p. 21] Até aqui, Benjamin: a impossibilidade de ter e transmitir experiências. No entanto, o texto continua: "Porém, nós hoje sabemos que, para a destruição da experiência, uma catástrofe não é de modo algum necessária, e que a pacífica existência cotidiana em uma grande cidade é, para esse fim perfeitamente suficiente. Pois o dia-a-dia do homem contemporâneo não contém quase nada que seja ainda traduzível em experiência: não a leitura do jornal, tão rica em notícias do que lhe diz respeito a uma distância insuperável; não os minutos que passa, preso ao volante, em um engarrafamento; não a viagem a regiões ínferas nos vagões do metrô nem a manifestação que de repente bloqueia a rua; não a névoa dos lacrimogêneos que se dissipa lenta entre os edifícios do centro e nem os súbitos estampidos de pistola detonados não se sabe onde; não a fila diante dos guichês de uma repartição ou a visita ao país de Cocanha do supermercado; nem os eternos momentos de muda promiscuidade com desconhecidos no elevador ou no ônibus. O homem moderno volta para casa à noitinha extenuado por uma mixórdia de eventos - divertidos ou maçantes, banais ou insólitos, agradáveis ou atrozes -, entretanto nenhum deles se tornou experiência." (p. 8) [N. do T.: Na tradução brasileira, p. 21-22] Benjamin e a primeira guerra; Kertész, os regimes totalitários e esse vazio que se chama liberdade ou democracia; Agamben e a vida cotidiana em uma grande cidade. O século XX. Um século em que se põem em funcionamento massivo uma série de dispositivos que fazem impossível a experiência, que falsificam a experiência ou que nos permitem desembaraçarmos de qualquer experiência. Talvez poderíamos pensar que essas experiências das quais falam Kertész, Benjamin ou Agamben, que podem ser atrozes, mas também banais, que podem ser extraordinários, mas também ordinários, nos dizem que nossa vida não é nossa vida, que o que nos passa nada tem a ver com nós. O texto de Benjamin está atravessado de nostalgia, é um texto elegíaco. O texto de Kertész está atravessado de desespero, é um texto desesperado. O texto de Agamben, entre nostálgico e desesperado, tenta abrir um espaço para pensar a experiência de outro modo, não como algo que perdemos ou como algo que não podemos ter, mas como algo que talvez, agora, se dá de outra maneira, de uma maneira para a qual, talvez, ainda não temos palavras. 
Detenhamo-nos, agora, nas últimas páginas de Sem destino, as que contam a volta do protagonista para sua casa após a liberação dos campos, um regresso tão absurdo e tão carente de sentido como a despedida do pai, como a captura na estrada, como o amanhecer na estação de Auschwitz, como a liberação, como a vida mesma ${ }^{16}$. Vamos começar de uma conversa do protagonista com um homem que conhece no bonde que o leva desde a estação ferroviária até a sua casa, um homem corpulento e barulhento que lhe paga o bilhete e que, suspeitando que o narrador volta de Auschwitz, trata de fazê-lo falar.

Já no bonde, a atitude desse homem contrasta com a atitude do homem uniformizado que controla os bilhetes, o que cumpre seu trabalho, o que, ao saber que o nosso protagonista não tem dinheiro para pagar, o responde que "a viagem tinha regras criadas não por ele, mas por seus superiores. 'Se não comprar um bilhete, vai ter que descer' - ponderou"17. E

\footnotetext{
${ }^{16}$ Queria fazer uma caracterização breve e, sem dúvida, superficial de Sem destino, sobretudo do que a obra não é. Certamente, a obra não é um romance moral ou moralista: não há nenhuma construção moral dos personagens nem dos acontecimentos. O que passa é descrito com absoluta neutralidade, com absoluta indiferença, como se fosse um fenômeno da natureza. Se "chover" é um acontecimento impessoal, "alguém morrer", "alguém ser torturado" ou "alguém passar fome" também são, nesse romance, acontecimentos impessoais, coisas que se sucedem "porque sim", sem mais. E coisas que se sucedem, também, a personagens sem apenas interioridade, sem apenas consciência. A obra não é, tampouco, um romance psicológico. Não há construção psicológica ou existencial do sujeito que vivencia os acontecimentos. Como se o narrador e o protagonista fossem idiotas, ou seres meio passados, embrutecidos, que contas as coisas como se não as tivesse vivido, como se estivesse ausente delas, como se não houvesse acontecido a eles, quase com orações impessoais, sem nenhuma distância crítica ou reflexiva, sem nenhum sentimentalismo, sem nenhuma profundida pessoal nem existencial, sem nenhum sentido. Em um dos trabalhos incluídos no livro deste congresso, há uma citação do meu amigo Marcos Villela que diz da experiência como uma marca da subjetividade e que diz assim: "a marca é um estado da prática do sujeito que tende a vibrar mais forte que as outras forças que atuam na zona de subjetivação. Ao vibrar mais forte, a marca dá o tom da orquestração" (em A estética da professoralidade. Um estudo interdisciplinar sobre a subjetividade do professor. Tese de doutorado. Pontifícia Universidade Católica de São Paulo. 1996). Se a experiência dá ao tom do sujeito, o tom psicológico, moral, existencial ou pessoal do sujeito, Sem destino seria um romance atonal. Em seus diários, Kertész diz assim: "Um romance atonal. O que é a tonalidade do romance? A diminuição contínua de uma moralidade determinada, o tom que ali sussurra em todos os momentos. Existe esse tom fundamental? Se existe, está esgotado. Um romance em que não apareça nenhuma moral estática, mas apenas as formas originárias do viver, a vivência em sentido puro e mistério de palavra" (em Diario de la galera. Barcelona: Acantilado, 2004, p. 67). De fato, a tonalidade supõe uma música subjetiva, expressiva, emocional, uma linguagem que oferece ao sujeito dispositivos de desintegração-integração que trabalham entre a ameaça do descentramento e o alcance desse centramento reparador, entre a perda provisória e a posterior afirmação de um eixo subjetivo. A música tonal é uma dança dramática na qual o drama é, precisamente, o território no qual se jogam os avatares da subjetividade. Poderíamos dizer, generalizando muito, que a tonalidade constitui uma linguagem para o drama da subjetividade, que a tonalidade é a projeção sonora da aventura subjetiva. A música atonal, por sua vez, deve supor uma certa dissolução tanto do sujeito como da experiência. Um "romance atonal" seria, então, como um romance sem aventura, sem drama, sem experiência, sem sujeito, um romance cheio de puras variações seriais sobre nenhum tema, "a vivência em sentido puro e mistério de palavra". A partir daqui poderíamos situar Sem destino nessa estirpe narrativa que se relaciona, provavelmente, com $O$ estrangeiro, de Camus, esse romance no qual se contam certos episódios da vida de Mersault, um estrangeiro para si mesmo e para o mundo, um ser puro e, portanto, absurdo, que está como se não estivesse, que é como se não fosse, como um intruso em sua própria vida, como um ser alheio a si mesmo que vive indiferentemente em uma pura duração bergsoniana, sem reflexão, sem antes nem depois, cuja primeira pessoa narrativa tem o valor neutro de uma terceira pessoa. Trata-se de uma estirpe narrativa que persegue a experiência pura, inocente, neutra, sem abstrações, sem interferências subjetivas; uma estirpe que atravessa o Nouveau Roman e que culmina com Peter Handke, grande poeta da desubjetivação e do estranhamento, o incansável caçador da experiência pura.

${ }^{17}$ Sin destino. Barcelona, Acantilado, 2001. p. 246. [N. do T.: Na tradução brasileira, p. 165].
} 
contrasta também com uma senhora idosa que, incomodada com sua presença, talvez sentindo-se acusada por ela, se distancia dele e olha com um olhar distante e uma expressão irritada para fora do bonde. Nenhum dos dois quer saber. O cobrador se esconde em suas rotinas de trabalho, no cumprimento de suas obrigações; a senhora olha para o outro lado. Certamente, o mesmo que fizeram durante os anos em que muitos de seus vizinhos eram detidos e deportados: seguir trabalhando e distanciar o olhar. Um modo como qualquer outro de seguir vivendo. Mas aquele homem não é como eles. Ele se diferencia dos outros depreciando-os, dizendo enfaticamente que "alguns teriam de se envergonhar."18 Ele não tem vergonha e nem deveria tê-la. Ele se interessa pela vítima, quer ajudá-lo, quer com ele falar e dele escutar. Construindo sua superioridade moral por contraste com a maldade dos outros, ao modo do fariseu, o homem do bonde quer fazer notar que ele não é como os outros. No entanto, o texto dá a sensação de que, aos olhos do protagonista, o cobrador e a senhora resultam menos suspeitos, menos perigosos e, inclusive, mais compreensíveis que esse homem que se interessa por ele dessa forma tão estranha e surpreendente.

O homem do bonde começa a perguntar com uma atitude compreensiva, mobilizando toda sua boa vontade. Perguntava como se já soubesse o que o outro iria dizer, como se já tivesse o nome adequado para aquilo que o outro passou, como se já soubesse de antemão qual é o valor e o sentido das experiências do sobrevivente dos campos. O homem, um jornalista que trabalha em um jornal democrata, pronuncia as palavras comuns, tranquilizadoras, as palavras que convertem o que se viveu em clichê, as que permitem desembaraçar-se da experiência, as que roubam a experiência pelo simples mecanismo de nomeá-la, de identificá-la, de falsificá-la. O homem fala do "inferno nazista" e dos "horrores" dos campos, diz que "o importante é que tudo acabou”, que o importante é "a cicatrização das feridas sangrentas e a punição dos culpados", que o que faz é "dar a conhecer os horrores", "mobilizar a opinião pública", lutar contra "a apatia, a indiferença, a dúvida"; diz que o que vai fazer é uma "exposição da verdade" para que possamos "confrontá-la". Temos, aqui, um caçador de testemunhos, um militante da memória, um ativista da verdade. Trata-se de alguém que pensa que as experiências do sobrevivente podem ter sua utilidade, sua função, sua razão de ser, seu sentido. Alguém que pensa que essas experiências podem servir para algo, que aquela vida não foi em vão, que o que passou "não é mais uma questão sua. É de todos, do mundo". Em seguida, ele propõe escrever uma série de artigos baseados no que o

${ }^{18}$ Idem. [N. do T.: Na tradução brasileira, p. 165]. 
protagonista lhe contar. Tentará, inclusive, fazer uma fotografia com ele e outra do momento de sua volta para casa, "transformar o acaso do reencontro num 'acaso feliz",19.

Todos vocês conhecem esse personagem, de sua versão mais nobre à sua versão mais degradante: o militante obcecado pela ética do testemunho e sua relação com a justiça, o historiador que dedica sua vida ao resgate de memórias anônimas e alheias, o escritor que usa as vidas dos demais como material de trabalho, o apresentador de um programa de televisão confeccionado ao modo dos reality shows, o repórter sensacionalista que entra em um galpão de um campo de refugiados (em Kosovo, na Costa do Marfim, no Paquistão ou em qualquer um desses lugares nos quais se instalam os circos midiáticos para produzir notícias que satisfaçam nosso insaciável apetite por informações e escândalos) com uma nota de cem dólares na mão e perguntando: "há aqui algum refugiado que fale inglês?" A operação sempre consiste em dar a palavra, em fazer falar, em construir sentido, em fazer com que os acontecimentos de uma vida sejam significativos ainda que os contextos e os modos de significação sejam os mais diversos e heterogêneos, alguns profundamente preocupados com a ética do relato e outros perfeitamente imorais.

Ao sobrevivente, o ativista da verdade que encontra no bonde faz lembrar o tio Vili e o tio Lajos, dois personagens que conhecemos no início do romance, na cena de despedida do pai, véspera de sua deportação. Ao tio Vili se respeitava porque havia sido jornalista, porque tinha informação, porque tinha opiniões solventes sobre o que estava passando. O tio Vili é aquele que vê as coisas de cima, de um modo geral, em contextos amplos, entendendo sua razão de ser e adiantando o possível curso dos acontecimentos. O tio Lajos era rabino. Ele também entendia o que estava passando, mas de outra perspectiva: a partir do destino comum dos judeus, da perseguição que sofrem a milênios, do castigo divino pelos pecados cometidos no passado. Nessa cena, ambos atuaram também como intérpretes legítimos dos acontecimentos, como proprietários de seu sentido, como aqueles que sabem de antemão o que nos passa e como devemos responder ao que nos passa. Ambos trataram de explicar à criança que nada entendia qual era o sentido do que estava passando, o que significava o que estava vivendo, como teria que se comportar, o que deveria pensar e o que deveria sentir. Eles fizeram algo semelhante ao que era feito, agora, pelo ativista da verdade: todos eles lhe constroem um destino. E isso pelo simples procedimento de inserir o que lhe passa ou o que lhe passou em uma trama, em um fio narrativo, em um argumento que vem de algum lugar e

${ }^{19}$ Idem. [N. do T.: Na tradução brasileira, p. 166-169]. 
que vai para algum lugar, em um tecido de sentido em que suas experiências significam algo que tem a ver com o geral, com o social ou político, com o histórico.

No entanto, o personagem de Sem destino resiste teimosamente a essa captura de suas experiências, a essa construção do seu destino que só entende como uma falsificação. O que lhe passou é o que lhe passou. O que fez não foi outra coisa senão adaptar-se a uma situação arbitrária e imposta, tentar entender sua lógica e comportar-se de acordo com ela, viver e continuar vivo. Algo que the parece completamente natural e banal, absolutamente insignificante. $\mathrm{O}$ mesmo que fizeram o cobrador e a senhora do bonde: passar o tempo como podem, tratar de seguir vivendo. O mesmo que fizeram os que no campo estavam do lado dos guardas: seguir trabalhando e desviar o olhar quando se passava algo vergonhoso ou insuportável demais, adaptar-se à situação, continuar vivendo nas circunstâncias que a cada um tocava, cumprir com suas obrigações. Uma hora depois da outra. Um dia depois do outro. Um ano depois do outro. Nada especialmente significativo. Nada que signifique outra coisa. Nada que não seja completamente insignificante: tão insignificante quanto a vida mesma.

O relato que o jornalista lhe oferece, tal como os que lhe ofereciam os tios, não se interessava pela sua experiência, mas por sua versão seletiva, mutilada, trucada; uma versão sociológica, política, religiosa ou moralmente falsificada. O jornalista quer construir um sentido que o sobrevivente não tem. O jornalista lhe pede suas experiências e lhe oferece, em troca, um sentido para suas experiências e um destino para o seu protagonista. Mas o narrador parece perceber vagamente, sabendo sem saber, que se lhe entrega suas experiências as perderá; que suas experiências, e ele mesmo como sujeito de suas experiências, serão aniquiladas.

5.

O grande momento da conversa com o ativista da verdade é a descrição do tédio nos campos. O narrador resiste a imaginar os campos como um inferno dizendo: "Nesse caso, eu o imaginaria [o inferno] como um lugar onde não haveria como se entediar [...], num campo de concentração o tédio era possível, até mesmo em Auschwitz - guardadas determinadas condições, é claro." 20 Ante a surpresa do jornalista por essas palavras, o narrador explica que isso é possível com o tempo, pelo uso constante do tempo, pelo passo gradual do tempo, passo a passo. E continua: "tentei explicar-lhe como era diferente chegar, por exemplo, a uma

${ }^{20}$ Idem, p. 248-249. [N. do T.: Na tradução brasileira, p. 167]. 
estação, se não exatamente luxuosa, mas no todo aceitável, limpa e bem-cuidada, onde, devagar, em ordem, aos poucos, tudo se aclara diante de nós. Ao passar por uma etapa, sabemos que depois de nós virão os seguintes. E assim sabemos de tudo, compreendemos tudo. E ao compreendermos tudo não ficamos sem agir: realizamos o nosso trabalho, vivemos, lutamos, movimentamo-nos, cumprimos as nossas exigências de cada nova etapa. Por outro lado, se essa sequência não existisse e se todo o conhecimento despencasse sobre nós de uma vez, é possível que o nosso cérebro e o nosso coração não suportassem [...].” E continua: "o equívoco, ou melhor, a desvantagem, é a necessidade de ocupar o tempo de algum modo. Vi, por exemplo, [...] prisioneiros que estavam ali havia quatro, seis ou até doze anos - mais precisamente: sobreviveram no campo de concentração. Esses homens tiveram de preencher todos os quatro, seis ou doze anos, ou os doze vezes trezentos e sessenta e cinco dias, ou seja, doze vezes trezentos e sessenta e cinco vezes vinte e quatro horas, e mais doze vezes trezentos e sessenta e cinco vezes vinte e quatro vezes... e tudo de novo a cada instante, minuto a minuto, de hora em hora, dia a dia. E também [...] é exatamente isso que deve tê-los ajudado porque se todo esse tempo de doze vezes trezentos e sessenta e cinco vezes vinte e quatro vezes sessenta e de novo sessenta vezes desabasse de uma vez num único golpe, na cabeça deles, nem eles teriam resistido - como resistiam -, nem com o corpo, nem com o cérebro. [...] É assim que devemos imaginá-lo".

Diante disso, o ativista da verdade esconde o rosto com as mãos e, antes de recuperar todos esses automatismos de sentido que lhe garantem a segurança em si mesmo e em seu trabalho, hesita por um instante e diz: "Não, não se pode imaginá-lo", e o protagonista pondera em pensamento: "[...] deve ser por isso que o chama de inferno"21. Aqui, a vida em Auschwitz, o que se vive em Auschwitz e a experiência de Auschwitz são contados, simplesmente, como passagem do tempo, como um emprego ordenado e sucessivo do tempo no qual acontecem essas coisas banais e insignificantes relacionadas com qualquer experiência do passar do tempo como, por exemplo, o tédio.

O tédio, o passar do tempo, o encaminhamento dos dias e das horas, das semanas e dos meses, dos minutos e dos segundos: o que não se pode contar. Mas não porque seja terrível, mas sim porque é banal, atrozmente banal ou banalmente atroz, insignificante, sem história. $\mathrm{O}$ passar do tempo não se converte em relato posto que se define por sua monotonia e por sua insubstancialidade, ainda que essa monotonia e essa insubstancialidade sejam feitas de extremo do sofrimento físico e rodeadas pelo cheiro de cadáveres em decomposição, e isso é

${ }^{21}$ Idem, p. 249-250. [N. do T.: Na tradução brasileira, p. 167-168]. 
precisamente o que o jornalista não pode, nem quer suportar. Isso e o fato de que o sobrevivente não tem nada a dizer. $O$ fato de que o sobrevivente se mantenha em sua inocência, em sua pureza, em sua idiotice, teimosamente resistindo à compreensão, à inteligibilidade, à representação, ao sentido. $\mathrm{O}$ fato de que queria manter ou guardar sua vida como incompreensível, como ininteligível, como irrepresentável, como carente de sentido. O sobrevivente rejeita qualquer sentido com o qual se envolve a sua experiência e, com essa rejeição, mostra a falsidade de qualquer um desses sentidos. A impressão que se tem é a de uma absoluta exterioridade entre o ativista da memória e o sobrevivente, como se não tivessem nada a ver um com o outro, como se não houvesse relação possível entre eles. O tédio nos campos é, sem dúvida, terrível; mas não é essa forma de horror que quer o jornalista. Ao mesmo tempo, o horror que o jornalista deseja é percebido pelo sobrevivente como uma falsificação. De quê? Da insignificância, da ausência de sentido, de algo que ao narrador parece completamente natural e insignificante: adaptar-se à situação, adaptar-se aos fatos, tratar de seguir vivo em qualquer circunstância, deixar o tempo passar.

6.

Depois dessa conversa, após jogar fora o pedaço de papel em que o jornalista havia anotado seu número de telefone e, com isso, a possibilidade que lhe foi oferecida de dar um sentido qualquer a suas experiências - seja esse sentido testemunhal, exemplar, político, ético ou histórico -, o narrador chega em sua casa. Em seu apartamento, agora, vivem outras pessoas que não lhe permitem entrar. Na volta para a escadaria, para no apartamento vizinho e então aparecem o rosto cinzento do Sr. Fleischmann e a barriga avantajada do Sr. Steiner, dois judeus que também conhecemos desde o primeiro capítulo, dois velhos que também assistiram à cena de despedida do pai. Após cumprimentos exaltados, informaram ao rapaz das novidades: seu pai morreu, sua mãe havia perguntado por ele, sua madrasta casou-se novamente. E os velhos começaram a contar: "Aqui em casa também não foi fácil.",22 Depois de escutar os relatos, o narrador comenta: "Do relato deles me vieram impressões, traços nebulosos de acontecimentos desordenados, confusos e impossíveis de acompanhar, que no fundo não fui capaz de vislumbrar ou compreender muito bem. Na ladainha deles notei mais a repetição frequente, quase cansativa, de uma palavra com que designavam toda a mudança, transformação, movimento: assim, por exemplo, 'veio' a casa da estrela, 'veio' o 15 de

${ }^{22}$ Idem, p. 255. [N. do T.: Na tradução brasileira, p. 171]. 
outubro, 'vieram' os nazistas, 'veio' o gueto, 'veio' a margem do Danúbio, 'veio' a libertação. E ainda o erro costumeiro: como se os acontecimentos já apagados, irreais, inimagináveis e, nos detalhes - como me parecia -, também para eles, impossíveis de serem reconstruídos, tivessem ocorrido na sequência normal dos minutos, horas, dias, semanas e meses, embora, por assim dizer, todos de uma vez, num único rodopio, numa vertigem, digamos, numa reunião vespertina estranha, tornada dissoluta quando os muitos participantes - uns, sim; outros, não - de súbito perderam a razão e por fim nem sabiam mais o que faziam, 23 .

Após essa narração dos tempos difíceis em Budapeste, nos quais tudo "veio", paulatinamente, ordenadamente, uma coisa depois da outra - ainda que no relato retrospectivo tudo parecia fazer parte de um turbilhão enlouquecido -, os vizinhos lhe perguntam por seus planos para o futuro dizendo-lhe que "devia esquecer os horrores", que tem que esquecer "para poder viver", que precisava se libertar desse fardo para "começar uma nova vida". O rapaz lhes dá razão, mas ao mesmo tempo não entende como vai esquecer essa vida se ela é, precisamente, a vida que viveu; e acrescenta: "Além disso [...] não vi horrores" ${ }^{24}$. Ante a surpresa por essa resposta, similar àquela do jornalista quando, ao perguntar ao sobrevivente pelo inferno dos campos, escutou sobre o tédio, o protagonista pergunta-lhes sobre o que fizeram durante aquele tempo. “'Bem... vivemos', ruminou um deles. 'Tentamos sobreviver' - completou o outro." A isso, o narrador comenta: "Ou seja: eles deram passos - observei. O que significava 'deram passos?', perguntaram, curiosos, e eu contei para eles como isso se passava em Auschwitz. Para cada carregamento - não digo que fosse sempre igual, pois não tinha como saber -, temos de contar cerca de três mil pessoas. Tomemos os homens, digamos, mil. Para o exame, calculemos de um a dois segundos - na maioria das vezes, um - para cada caso. Não contemos o primeiro e o último, pois esses nunca contavam. Porém, no meio, onde eu também estava, temos de imaginar de dez a vinte minutos de espera até a chegada ao lugar onde se decide: gás de imediato ou uma chance temporária. Enquanto isso a fila se move, avança, e todos dão um passo, menor, maior, segundo a velocidade exigida"25.

As coisas chegam uma atrás da outra, mas nós também avançamos, passo a passo. Essa é a textura da experiência. Isso é o ininteligível, o incompreensível, o que não tem outro sentido distinto desse - se é que desse se pode chamar sentido. Ninguém sabe o que chega enquanto está chegando, ninguém sabe para onde avança enquanto avança, enquanto dá

\footnotetext{
${ }^{23}$ Idem, [N. do T.: Na tradução brasileira, p. 171].

${ }^{24}$ Idem, p. 256. [N. do T.: Na tradução brasileira, p. 172].

${ }^{25}$ Idem, p. 256-257. [N. do T.: Na tradução brasileira, p. 172].
} 
passos. Só um olhar projetivo ou um olhar retrospectivo podem dar um sentido geral a esse passar do tempo. No entanto, esse sentido geral é falso: “[...] independente de olharmos para trás ou para frente, ambos são perspectivas equivocadas - refleti. Afinal, vinte minutos num momento desses, ou tomados em si, são muito tempo. Todo minuto começou, durou, encerrou-se antes de se iniciar uma vez mais o seguinte" 26 .

Os passos desses vinte minutos e os passos de toda a vida, de qualquer vida, não são essencialmente distintos. Todos estavam dando passos enquanto podiam: o tio Lajos e o tio Vili, o senhor Fleischmann e o velho Steiner, o jornalista, o cobrador do bonde, a senhora que desvia o olhar, as vítimas e os carrascos, os comprometidos e os indiferentes, os mortos e os sobreviventes; e também o protagonista, não só na fila de Auschwitz, mas antes, em sua casa, com seu pai, com sua mãe, com sua vizinha Annamária, com sua madrasta, com sua irmã mais velha... E depois também continuará dando passos, um após o outro, nesse porvir incerto e desconhecido que chega aos poucos e no qual seguimos vivendo. As últimas linhas do romance parecem uma prefiguração da falta de sentido desses passos futuros: "Minha mãe me esperava e vai ficar feliz de verdade, a coitada. Lembro que um dia seu plano era que eu fosse engenheiro, médico ou coisa parecida. E assim será, com certeza, como ela deseja; não há impossibilidade que eu não possa viver, naturalmente, e sei que no meu caminho me espreita, como uma armadilha inevitável, a felicidade. Pois lá, entre durezas, havia, na pausa das torturas, alguma coisa que se assemelha à felicidade. Todos perguntam apenas das condições, dos 'horrores', ao passo que, para mim, a experiência mais memorável é esta. Sim, da próxima vez, se me perguntarem, eu deveria falar disso, falar da felicidade nos campos de concentração. Se me perguntarem. E se eu não me esquecer"27.

A textura da experiência é esse passo a passo em que cabe o tédio e, às vezes, como uma armadilha inevitável, a felicidade. Dir-se-ia que Kertész está descobrindo a vida nua, essa vida genérica determinada como sobrevivência que os gregos nomearam com a palavra zoé, oposta de biós. Zoé, de onde vem zoologia, nomeia a vida genérica, a vida como sobrevivência, essa vida cuja qualidade se mede por sua duração e pelo balanço entre prazer e dor, essa vida que não é de ninguém porque é de qualquer um, porque é para todos igual e porque, em relação a ela, todos somos substituíveis e intercambiáveis. Biós, de onde vem biologia, no entanto, se refere à vida de alguém, aquela que é susceptível de converter-se em biografia, essa vida propriamente humana, individual, única e insubstituível, tanto que está tramada em uma rede de sentido ou de sem-sentido, essa vida que é de cada um e de cada um

\footnotetext{
${ }^{26}$ Idem, p. 257-258. [N. do T.: Na tradução brasileira, p. 172-173].

${ }^{27}$ Idem, p. 262-263. [N. do T.: Na tradução brasileira, p. 175].
} 
distinta, a cada um a sua, essa vida para a qual as experiências têm um sentido próprio, singular, subjetivo, de alguém. Dir-se-ia que Kertész está tramando de mostrar sem dizer, como fazem os artistas, que a condição dos campos e, por extensão, a do totalitarismo e, também por extensão, a do século XX, é a redução da experiência à zoé, à pura sobrevivência. Trata-se apenas de viver a qualquer preço, de continuar vivendo. Passo a passo.

Os indivíduos não podem dar sentido a suas experiências porque carecem justamente de tudo aquilo com o que poderiam tecer esse sentido. Os indivíduos simplesmente se adaptam. A quê? Aos fatos, a qualquer desses absurdos que chamamos fatos. O tempo se converte, assim, em um tempo vazio, morto, feito de morte e de administração da morte, que tem que chegar e tem que passar. E isso é precisamente o obsceno, o que é deixado de fora da cena, o que não se pode dizer, o que não cabe em nenhum dos grandes relatos da história, do progresso, da política ou da religião. O que não cabe em nenhum romance entendido como construção articulada e grandiloquente da experiência. O que não cabe sequer em um pequeno relato pessoal e existencial ancorado no mito da profundidade da alma. O que não se converte em relato é a vida cotidiana, essa vida ridícula, idiota, incontável, aderida aos acontecimentos elementares. Essa vida que, precisamente por estar vazia de sentido, é uma vida na qual tudo o que passa resulta gratuito, súbito, arbitrário ou brutal.

A questão aqui é qual seria o relato capaz de deixar aparecer a experiência tal como é, em sua radiante idiotice, em sua banalidade mais pura, sem acrescentar nada. Qual seria o relato capaz de capturar a impossibilidade da experiência, a ausência de sujeito. Qual seria o relato capaz de se apresentar a si mesmo como o relato insignificante de alguém insignificante que vive uma vida insignificante. Qual seria esse relato que nas entrelinhas se lê o que não está relatado. Qual seria o relato capaz de dar o ponto de vista não daquele que escolhe entre vários destinos, não daquele que quer dar um sentido a sua vida e triunfa ou fracassa, mas o do homem esmagado pelo destino, do homem que se adapta a viver na falta de destino. Qual seria o relato que nos daria a sabedoria de ver que não somos, de compreender que não compreendemos, de saber que não sabemos, de viver o que não vivemos. Qual seria o relato desse não ver, desse não compreender, desse não saber e desse não viver que, uma vez intuído, já nunca nos abandonará.

Para mim, as vinte últimas páginas de Sem destino são exemplares a esse respeito. Diante do narrador, duas alternativas se abrem. A primeira é a destruição da experiência pelo esquecer. Simplesmente, tem que seguir vivendo e, para isso, tem que esquecer esses vinte minutos na fila. Essa é a posição do tio Vili e do tio Lajos. Assim, sua experiência se reduzirá, com o passar do tempo, a uma vaga impressão e a algumas anedotas. A segunda alternativa é 
a falsificação de suas experiências pelo recurso de fazê-las significativas. Essa é a posição do jornalista. Tem que sentir esses vinte minutos na fila como algo insuportável e inventar com isso um relato que os aniquile ao mesmo tempo que os falsifique. Outra forma de destruição da experiência. Essa é a posição dos fabricantes de sentido, dos redentores e dos consoladores de todas as espécies, dos que querem salvar aos demais e salvarem-se a si mesmo do delito de não ser ninguém, do pecado de não ter nada a contar, nada a dizer, que não seja essa experiência falida, fragmentária, insignificante, banal; essa experiência da ausência da experiência. Para mim, a lição de Kertész é manter-se fiel a esse sem destino. Tratar de vê-lo e de fazê-lo ver, de compreendê-lo e de fazê-lo compreender, de sabê-lo e fazê-lo saber, de vivê-lo e de transmití-lo. Kertész trata de manter-se fiel a essa idiotice, a essa inocência, a essa sensação de irrealidade, a essa falta de sentido.

\section{7.}

Os vinte minutos de fila na chegada de Auschwitz, esses vinte minutos de espera diante dos médicos que vão decidir quem vai ou não seguir com vida, constituem, provavelmente, o episódio mais importante de Sem destino, o mais inassimilável por seu conteúdo e o mais surpreendente do ponto de vista formal, dado o modo como está contado. Esse episódio tem um papel fundamental nas reflexões que seguem a rejeição editorial do romance, tal como se conta no longo prólogo de O fiasco. E também a esse episódio se dedica Kertész em boa parte de seu discurso de recepção do Nobel, na cidade de Estocolmo, em 7 de dezembro de 2002.

Em algumas das páginas de $O$ fiasco, Kertész dá-se conta de suas experiências acerca do que significa escrever para outros. Primeiro, em uma entrevista com os responsáveis da editora a qual havia entregado seu manuscrito, percebe imediatamente que "estava sentado diante de um humanista profissional" cujo desejo está voltado para invalidar suas experiências. Para esse humanista profissional, o importante é que Auschwitz não maculasse o Ser Humano e que, tampouco, maculasse os que leem o romance "com a maior boa vontade" 28 , quer dizer, os outros humanistas como ele.

Segundo, a propósito da carta em que a editora lhe comunicava que não iria publicar seu romance. Nessa carta diz-se que o tema é impressionante e chocante, mas que não pode converter-se em uma experiência também impressionante e chocante para o leitor visto que "a

${ }^{28}$ Fiasco. Barcelona: Acantilado. 2003. p. 41. [N. do T.: Na tradução brasileira, p. 39-40]. 
redação artística de seu enredo não foi muito feliz", especialmente "as estranhas reações, para dizer o mínimo, do protagonista." O que surpreende ao editor é a descrição quase bucólica do amanhecer na estação de Auschwitz, o fato de que o protagonista considere "suspeita" a aparência dos prisioneiros de cabeça raspada que se encarregam de descarregar o vagão, a sensação de "tratar-se de uma travessura de estudantes" que deriva do modo como conta a maneira de enganar os médicos para que lhes considerem aptos para o trabalho. O comentário final diz assim: "Seu comportamento, suas observações embaraçosas, repelem e ofendem o leitor, que lê, aborrecido, também o desfecho do romance, pois o comportamento do protagonista até esse ponto, sua indiferença não dão base para que ele possa julgar moralmente, ou responsabilizar alguém (por exemplo, as reprimendas feitas à família judia que morava em sua casa)" ${ }^{\prime 29}$.

Terceiro, em uma conversa com alguns colegas escritores na qual esses lhe aconselham o que poderia fazer para que o manuscrito fosse publicado: fazer-se um nome, tratar um tema desses que estão no ambiente, ou desses que podem ser úteis a algum grupo organizado como argumento ou como contra-argumento, como bandeira ou como obstáculo, ser preso para poder ser apresentado como um escritor perseguido por suas ideias, unir-se a uma corrente literária ascendente, ficar nu em uma recepção oficial, professar em um estranha seita, divorciar-se e voltar-se a casar, ser internado em um hospital psiquiátrico ou realizar qualquer uma dessas operações trivialmente escandalosas que fazem que um nome circule nos jornais.

A ninguém interessam esses vinte minutos na fila, a ninguém parecem interessantes e, portanto, ninguém os lê ou, o que é dizer o mesmo, todos os leem, mas a partir do que não são: não são vinte minutos "humanistas", não são vinte minutos "impressionantes e chocantes", não são vinte minutos a partir dos quais se podem emitir juízos morais corretos, desses que condenam os que são obviamente os maus, sempre os outros, e santificam os que pertencem ao grupo dos bons, sempre nós. Os editores só poderiam lê-lo se pudessem apropriar-se de suas experiências, dá-las um sentido, fazê-las significativas para uma ou outra causa, utilizá-las e, portanto, falsificá-las e destruí-las. Por outro lado, a ninguém interessa o homem ao qual esses vinte minutos aconteceram, a ninguém ele parece um homem interessante: não é nada, não pretende representar nada, nem sequer pode ser consumido como um personagem estranho ou extravagante.

${ }^{29}$ Idem, p. 59-60. [N. do T.: Na tradução brasileira, p. 55-56]. 
No discurso de Estocolmo, Kertész diz que se houvesse pensado no mercado do livro, sem dúvida teria buscado uma forma romancista mais brilhante. Poderia, por exemplo, fragmentar o tempo da narração para contar apenas os acontecimentos mais chocantes, mas "a linearidade exigia que cada situação se cumprisse integralmente. Impedia-me, por exemplo, de saltar alegremente vinte minutos, simplesmente porque esses vinte minutos abriam-se diante de mim como um abismo escuro, desconhecido e espantoso, como uma fossa comum. Falo desses vinte minutos que passávamos na plataforma de chegada do campo de BirkenauAuschwitz, antes que as pessoas que desciam dos vagões se encontrassem com o oficial que fazia a seleção. Eu mesmo recordava em grande parte aqueles vinte minutos, mas o romance exigia que desconfiasse de minha memória. Todos os testemunhos, confissões e recordações dos sobreviventes que li, no entanto, estavam de acordo no fato de que tudo acontecia muito rápido e na maior das confusões: as portas dos vagões abriam-se violentamente em meio a gritos e latidos, os homens e as mulheres eram separados e, em meio à multidão insana, se encontravam com um oficial que lhes dava uma rápida olhada, sinalizava algo com o braço estendido e, sem se dar conta, já iam vestidos de prisioneiros. Eu tinha outra recordação desses vinte minutos. Fizeram chegar em minhas mãos uma série de fotografias que um SS havia feito da chegada a plataforma de Birkenau e que os soldados americanos encontraram em um campo liberado de Dachau, em um antigo quartel da SS. Olhei essas fotos com perplexidade: caras bonitas e risadas de mulheres, jovens de olhar responsável, cheios de boa vontade e dispostos a cooperar. Então, compreendi porque esses humilhantes vinte minutos, de inação e de impotência, haviam sido apagados de sua memória. E quando pensei que tudo isso se repetiu dias após dias, semanas após semanas, meses após meses, durante longos anos, pude ter uma ideia da mecânica do terror; entendi como a natureza humana podia voltar-se contra a própria natureza humana" ${ }^{\prime 3}$.

Além da evidente falsificação que supõe escrever para outros, para capturar o que se supõe ao interesse dos outros, Kertész é também consciente dos paradoxos e da impossibilidade de escrever para si mesmo. Algumas páginas de $O$ fiasco têm a ver com isso, com essa dupla impossibilidade de escrever para si: com a impossibilidade de ler o próprio relato como se fosse alheio e com a impossibilidade de lê-lo como se fosse próprio. O relato, para o escritor, não é próprio nem alheio, ou é, ao mesmo tempo, próprio e alheio. $\mathrm{O}$ protagonista de $O$ fiasco, enfrentando a rejeição de seu romance, se encontra diante da impossibilidade de dizer se seu romance é bom ou ruim. Primeiro, tenta lê-la como se fosse

\footnotetext{
${ }^{30}$ iEureka! Discurs de recepció del premi Nobel de Literatura. Em Central. Lectura, memória i tolerància. Barcelona: Companya Central Llibretera, 2003, p. 85.
} 
alheia, mas é incapaz de saltar sobre si mesmo para ler seu próprio relato de uma distância adequada. Depois, tenta lê-la como se fosse própria, mas o relato não pode ser seu; o único que pode ler, o único que existe, é uma história pertencente a sua imaginação, uma história escrita. O que ocorreu, então, à matéria da experiência no fato de descrever com ela um relato? O narrador sente que Auschwitz estava em seu interior, que qualquer coisa estimulava a recordação e, portanto, o relato. $\mathrm{O}$ narrador sente que, ao escrever, estava tomado por sua própria vida; sente que está rico, pesado e maduro de sua própria vida. Mas, nessa tecitura, sente que é como um pereiro silvestre disposto a dar pêssegos. A escrita lhe parece uma atividade de consumo de experiências, um trabalho feito a partir de uma coleção de experiências armazenadas e armazenáveis, cada vez mais tênues e distantes, cada vez mais estereotipadas na memória, que, para serem comunicadas, têm que ser transformadas em material artístico. Fazer comunicável a experiência significa escrever para outros, converter a própria vida e a própria pessoa em objeto, usar signos abstratos e impotentes. Escrever significa, portanto, enganar e enganar-se, começar a sentir em si mesmo o cheiro de livro mofado.

\section{8.}

Provavelmente seja suficiente. No entanto, há outra fila e outros passos na obra e na vida de Imre Kertész que não posso deixar de comentar posto que elas constituem a origem dessa fúria literária da qual emerge o Kertész escritor. Estamos no final de $O$ fiasco, o final de um romance de contornos autobiográficos no qual se conta a vida na Hungria comunista. Uma vida na qual o protagonista, Köves, dá passos, um após o outro, buscando entender uma realidade absurda na qual as coisa chegam; segue vivendo dia após outro, passo a passo; vivendo como se sua vida não fosse sua, muitas vezes entediado e, em outras, surpreendido por algo que se assemelha à felicidade. Estamos em uma manhã de primavera de 1956. Chegou ou estava chegando o que ainda não se sabe que será a Revolução Húngara, um levante popular contra o stalinismo que será esmagado pouco depois. Os amigos de Köves, nervosos e alvoroçados em um café chamado Mares do Sul, preparavam um cartaz com as palavras “Queremos viver!” Os diretores do escritório em que trabalha também estavam inquietos, como que pressentindo a mudança, preparando-se para algo que ainda não sabiam o que era. Alguns aproveitavam a súbita desordem para preparar a saída do país. Anunciava-se outra "liberação". Köves estava no escritório, em um corredor em forma de "L", esperando que alguém o recebesse. De repente, escutou passos em ritmo de marcha na outra parte do 
corredor. Sem dúvida se tratava de uma só pessoa, de um escriturário que ia de uma sala a outra. Mas Köves sentiu como uma imensa marcha, como uma multidão que o atraía, o arrastava, incitando-o a aderir-se à ela, a seguir os passos entusiasmados dessa multidão em fila, a unir-se ao seu calor, à sua segurança, à sua cegueira. E nesse mesmo instante, "enxergou alguma coisa também no corredor - uma visão sombria, indistinta, que se parecia com o fantasma afogado que perseguia em seus sonhos. Claro, Köves só via o afogado da mesma forma que ele enxergava a multidão: isto é, ele não tinha nem um nem outro; no entanto, sua sensação era de estar vendo - era sua unicidade que estava se debatendo ali, sua vida abandonada, sem dono" ${ }^{\text {31 }}$. Köves percebe, sombriamente, que se, se unir a esses passos que o chamam, submetendo-se a esse "Queremos viver!" que move a multidão, trairá esse estranho afogado nebuloso que também é ele mesmo. Sabe também que, se saltar da fila, esse afogado o arrastará consigo para sua profundidade. E, nesse momento, ele, ou algo nele, decide afastar-se da fila e escrever o romance.

No discurso de Estocolmo, Kertész refere-se a esse momento em uma reflexão sobre o porquê de sua escrita. Conta, então, da força de atração desses passos, seu magnetismo tentador, seu convite ao abandono de si mesmo. Conta da intensidade dessa experiência, seu caráter revelador, sua qualidade de tomada de consciência existencial. Dessa experiência, diz o seguinte: "Não ofereço minha arte - para a qual demorei muito tempo para ter as ferramentas -, mas minha vida que quase perdi. Tratei da solidão, de uma vida mais difícil, de sair deste namoro inebriante, dessa história que deixa o homem sem sua personalidade e o converte em um ser sem destino. Constatei com espanto que dez anos depois de voltar dos campos nazistas e, de alguma forma, com o pé sobre o terrível encantamento do horror stalinista, não me ficaria outra coisa que não uma impressão vaga e algumas anedotas. Como se tudo isso não tivesse passado a mim" ${ }^{32}$.

É necessário sair da fila motivada pela vontade de viver, pela cega obsessão em seguir vivendo em qualquer circunstância, minuto a minuto, dia a dia, ano após ano, a qualquer preço. Temos que nos afastar desse desfile em que todos caminham juntos, passo a passo, rumo à uma morte mais distante ou mais próxima, mais normal ou mais brutal. Trata-se de recuar, de renunciar a vida, de deixar mentir e mentir-se. Trata-se de escrever: "Tudo o que tinha acontecido e estava acontecendo, o que a ele tinha acontecido e estava acontecendo, e nada poderia acontecer no futuro sem essa consciência afiada. Enquanto ele ainda estava vivo - já quase havia vivido toda a sua vida -, de repente viu, a uma grande distância, algo como

${ }^{31}$ O fiasco. Op. Cit. p. 363. [N. do T.: Na tradução brasileira, p. 357].

32 iEureka! Discurs de recepció del premi Nobel de literatura. Op. Cit. p. 85. 
uma forma fechada, perfeita, redonda, tanto que foi surpreendido por sua estranheza. Como poderia imaginar a possibilidade de se esconder, de livrar-se do fardo de viver como um animal em sua jaula? Não, não. Assim, devemos viver a partir de agora, com o olhar cravado na existência, contemplando-a por longo tempo, com olhar penetrante, espantado e incrédulo, e não deixaria de contemplar até descobrir nela algo que quase já não pertencia mais a essa vida, algo palpável, agarrado à essência, indiscutível e acabado como as catástrofes, algo que se desprendia pouco a pouco dessa vida como um cristal de gelo, algo que qualquer um poderia levantar para observar sua forma definitiva e passá-lo a outro, a fim de examinar essa notável estrutura da natureza" ${ }^{33}$.

\section{9.}

Disse-lhes no início de minha intervenção que não sabia se esta conferência ia ser um passo à frente, um passo atrás, ou um passo ao lado, nisso de problematizar a relação entre relato, experiência e subjetividade. Disse-lhes também que pensar não é algo que nos põem as coisas mais fáceis, mas que, pelo contrário, nos põem mais difíceis e que, justamente por isso, vale a pena. Além disso, disse-lhes que talvez atiraria pedras sobre o nosso próprio telhado. Agora, tenho a sensação de que não fiz nada disso. O que fiz foi, simplesmente, contar-lhes minha leitura das últimas páginas de Sem destino tratando de expressar, com elas, algumas de minhas perplexidades. No entanto, fui incapaz de converter essas perplexidades em algo que se pareça com a fundamentação ou a crítica disso que chamamos pesquisa (auto)biográfica. A partir dessa leitura de Kertész, está claro, ao menos para mim, que nós estamos mais próximos do jornalista e dos tios Vili e Lajos do que de qualquer um dos outros personagens do romance. A radical exterioridade entre qualquer tipo de pesquisador - seja um juiz, um jornalista, um historiador, um pedagogo, um sociólogo, um antropólogo etc. - e as existências que usa como objeto ou produto de seu trabalho. Um pesquisador sempre produz sentido. Busca que as experiências com as quais trabalha signifiquem algo, representem algo. Busca

\footnotetext{
${ }^{33}$ Relacionei antes a escrita de Kertész com Camus, com o Nouveau Roman, com Peter Handke. Mas o final desse fragmento não cessa em me fazer pensar em Clarice Lispector. Também a Macabea, de $A$ hora da estrela, forma parte desses inocentes, desses idiotas, desses seres que quase não são ninguém ou nada, desses personagens sem interior, sem consciência, quase sem palavras; desses sujeitos que não são sujeitos, que não têm história, que não têm nada a contar. Também a Macabea, de A hora da estrela, de Lispector, como o Mersault de $O$ estrangeiro, como o Mathias, de El mirón, de Robbe-Grillet, como o Bloch, de El miedo del portero al penalty, de Handke, encarnam a existência como "algo que quase já não pertencia mais a essa vida, algo palpável, agarrado à essência, indiscutível e acabado como as catástrofes, algo que se desprendia pouco a pouco dessa vida como um cristal de gelo, algo que qualquer poderia levantar para observar sua forma definitiva e passá-lo a outro a fim de examinar essa notável estrutura da natureza".
} 
que, através delas, algo se compreenda. Porém, a experiência singular sempre tem algo de incompreensível, de ininteligível, de irrepresentável e de inidentificável; algo ao qual deve exercer traição e violência para que se converta em outra coisa. É possível que o que chamamos experiência e o que chamamos identidade não sejam nada mais que o resultado dessa violência e falsificação.

Como produzir sentido sem mentir, sem violentar, sem falsificar? Para isso teríamos que problematizar constantemente o que nosso olhar tem de vertical, de assimétrico, de colonizador. Teríamos que problematizar também o que o nosso olhar tem de homogeneizador, de banalizador, de falsamente igualitário; o que o nosso olhar tem de estereótipos, de generalizações, de abstrações identitárias e identificadoras. Nós somos os senhores da língua, os donos da representação, os proprietários do sentido. Nós, os universitários, os pesquisadores, os intelectuais, os escritores, os que trabalham com as palavras e com as ideias, somos como o jornalista de Sem destino. Nós somos os que estabelecemos a relação legítima entre as palavras e as coisas, entre a experiência e o sentido, os que clarificam, ordenam e escrevem o mundo, os que têm a arrogante pretensão de conhecê-lo, julgá-lo, transformá-lo. Nós somos os moralistas, os que falam dos outros para justificar a nós mesmos, os que falam em nome dos outros para ter algo a dizer, os que convertem as experiências e as subjetividades dos outros em experiências e subjetividades compreensíveis, inteligíveis, representáveis, identificáveis. Nós somos os que convertemos as vidas e as palavras dos outros em saber, em conhecimento, em informação, em cultura, em mercadoria. Teríamos que problematizar constantemente nossos conceitos, nossas teorias, nossos métodos. E para essa problematização, ao que me parece, deveríamos atender às lições dos escritores, dos narradores, dos poetas. Ainda que não saibamos o que fazer com elas. Ainda que nos deixem, às vezes, perplexos, sem palavras.

Quero lhes dizer agora, para terminar, que eu, assim como vocês, vou seguir construindo relatos, nomeando experiências, tramando sentidos, produzindo subjetividades. Vou continuar contando e escutando, escrevendo e lendo, relatos de experiências. Vou continuar habitando esse emaranhado de relatos, experiências e subjetividades que é a vida. No entanto, ao mesmo tempo, e graças ao trabalho e à honestidade de pessoas que têm escavado mais fundo e que têm percebido com mais precisão, tratarei de conservar a suspeita de que não é a vontade de saber o que faz justiça à vida, de que no fundo não sei. Graças a alguns artistas da insignificância, não me abandonará nunca esse saber que não sei, esse compreender que não compreendo, essa certeza de que a experiência é uma matéria tênue e fugidia que se destrói e se falsifica quando se quer dominar, quando a ela se comete uma 
violência; e que escapa entre os dedos, como a água, como uma pele amada, como a vida mesma, quando a desejamos paz, quando a tratamos com ternura. Não me abandonará nunca essa sensação de que é precisamente quando não somos ninguém em particular que a experiência se dá com especial intensidade ao tempo que nos faz inapropriados em sua insignificância. Queria advogar aqui por essa ternura. Uma ternura que não está desprovida de atenção, de paciência, de respeito, de sofrimento e, às vezes, de silêncios. E que tem a ver, de forma não desenhável, com algo que, por falta de uma expressão melhor, chamarei de honestidade na linguagem, na escrita.

Submetido em Agosto de 2013. Aprovado em Janeiro de 2014. 